\title{
Hots-Based Learning in 2013 Curriculum: Is it Suitable?
}

\author{
Nita Pratiwi ${ }^{1 *}$, Ali Mustadi ${ }^{2}$ \\ 1,2 Department of Primary Education, State University of Yogyakarta, Yogyakarta, Indonesia \\ e-mail: nitapratiwi.2019@student.uny.ac.id ${ }^{1}$, ali mustadi@uny.ac.id²
}

\begin{abstract}
This study aims to evaluate the suitability of the HOTS-based learning process with the Minister of Education and Culture Regulation Number 22 of 2016. This study is an evaluation study with Stake Countenance Models. Evaluation is carried out through evaluation stages, namely: Antecedent stage; Process Stage (transaction); and Outcomes stage. Respondents in this study were 98 people who were selected using the Stratified Random Sampling technique. The results showed that HOTS-based learning has not been fully achieved, namely for the implementation of HOTS in the 2013 curriculum in the incomplete category at 3\%; a quite complete category at $9.44 \%$; a complete category at $62.44 \%$; and a very complete category at $25.11 \%$. So, can be concluded that not all HOTS-based learning processes have been implemented suitable with the Minister of Education and Culture Regulation Number 22 of 2016.
\end{abstract}

Keywords: Higher Order Thinking Skills, Curriculum

\section{Introduction}

Science and technology advancement creates various and different jobs and social interaction from the previous era. Problems and challenges engaged by the human in the future will be more complicated. Therefore, education should also be ready to engage these dynamics by preparing learners with higher-order thinking skills. Formal education at schools that apply the 2013 curriculum is expected to have a paradigm change dealing with its learning. It should move from teacher-centered learning to student-centered learning (Erlin \& Ernawati, 2019). Efforts to improve learning and teaching quality and quantity require teachers to master their teaching-learning plans. Teachers need to plan to carry out a learning process through the lesson plan as the reference and learning achievement standard. Therefore, teachers should be more critical to arrange their lesson plans, mostly dealing with the targeted competence and learning core activities based on $21^{\text {st }}$-century skills. $21^{\text {st }}$ skills have several features that require learners to apply Higher Order Thinking Skills.

Teachers need to be more creative and innovative to facilitate active learning for students. They also have to stimulate learners to think critically and analytically or even create science works, such as creating simple water filters or creating play dough from surrounding goods. In other words, learning should be at a higher level by implementing HOTS-oriented learning. It could be realized on the cognitive, affective, or psychomotor aspects. The notions are consistent with (Musfiqi, S., \& Jailani, 2014). They argue that Higher Order Thinking Skills (HOTS) is a thinking process involving critical and creative information management to solve particular problems. HOTS-oriented learning is an effort to improve learning and graduate qualities (Setiawati, 2019).

Curriculum 2013 fosters learners to have a qualified human resource to compete in this global era. The globalization era demands learners to have $21^{\text {st }}$-century skills. The skills are higher-order thinking skills. Higher-order thinking skills are needed in every learning process to improve learners' qualities and education. Learners should reach the targeted competencies such as critical thinking, creative and innovative, communication, and collaborative skills. They also need to have high confidence in higher-order thinking skills.

HOTS typed questions require learners to think highly. It also involves the reasoning process to train their critical, logical, reflective, metacognitive, and creative skills. (Suryapuspitarini, B, K., Wardono., \& Kartono. , 2018) HOTS typed question arrangement on

\footnotetext{
${ }^{*}$ Corresponding author.

Received 30 December 2019; Accepted 30 July 2020; Available online 25 March 2021

(c) 2020 JPI. All Rights Reserved
}

Jurnal Pendidikan Indonesia (JPI) | 128 
learning has the purpose of allowing learners to think divergently instead of convergent. Divergent thinking allows learners to not only answer questions correctly. However, learners need to think several analytical answers and problems on the questions.

The success of HOTS development is also determined by the consistency of the targeted learning outcomes, as stated in the curriculum document and the applied assessment (FitzPatrick, B., \& Schultz, H., 2015). The reason is - assessment correlates strongly to teaching and learning (Baird, J., Andrich, D., Hopfenbeck, T. N., \& Stobart, G., 2017). The measurement of HOTS should apply understandable instruments for primary school learners. HOTS also require complex thinking activities. (Budsankom, P., Sawangboon, T., Damrongpanit, S., et al., 2015, p. 2650) Argue that HOTS is a skill to determine an answer or target through reasoning processes (Tyas, D., Dian, I. K., 2019). Significant learning allows learners to improve their higher-order thinking skills, mostly dealing with the targeted problem solution through various learning activities. Learning that emphasizes on such matter is known as Higher-Order Thinking Skill Oriented Learning.

The Australian Council for Educational Research (ACER) (2015) states that higherorder thinking skills involve analyzing, reflecting, arguing, applying the various concept, arranging, and creating. Higher-order thinking skills is not a skill to memorize, recognize, or repeat. It deals with problem-solving, critical thinking skills, creative thinking skills, reasoning, and decision-making. One of HOTS learning features is allowing learners to think divergently. It involves several possibilities, alternative answers, and various thoughts.

From the observation of the whole primary schools in Depok district, Special Region of Yogyakarta, many teachers had not effectively applied the expected skills of HOTS-oriented learning. Moreover, some of them also had not understood about HOTS. Researchers applied the already arranged Lesson Plan to find out the learning implementation. It had the purpose of finding out whether the schools had been directed to HOTS for improving the learners' thinking skills or the learning remained on teacher-centered learning style. This learning would only allow learners to observe and memorize materials because HOTS could improve qualified learning from cognitive, affective, and psychomotor aspects. 2013 curriculum requires teachers to make HOTS-oriented learning that allows learners to analyze, evaluate, and create based on the Regulation of Cultural and Educational Ministry Number 22 the Year 2016. Learners should understand, analyze, categorize, manipulate, create, and implement new ways creatively to find a solution toward new problems (Riadi. A, \& Retnawati, H, 2014).

It influences the teacher's implementation. Before applying the learning, teachers must arrange Lesson Plan as a reference to promote learning. Many teachers did not understand what HOTS was. It could be seen from the formulations of indicators, objectives, methods, media, learning activities, designed-lesson plans, and learning processes. Many teachers were found not capable of reaching the expected skills of HOTS-oriented learning effectively. The teachers also did not understand about HOTS improvement. Teachers should be able to develop and covert Lower Order Thinking Skills into Higher Order Thinking Skills. The Lesson Plan design arrangement should initiate it so the HOTS learning process could be carried out in the class.

Learners should master HOTS in 21 $1^{\text {st }}$-century learning (Farisi, 2016; Garcia, 2015). This skill could be mastered when learners are trained in learning. Teachers could use various learning models and HOTS questions to train learners' skills. 2013 curriculum aims to prepare Indonesian humans having life skills, to be creative, productive, innovative, effective, and contributive toward social life, national life, and world civilization (Mendikbud, 2013e, p. 80). Principally, all education levels demand learners to have a high HOTS score. (Baris, 2015; Copley, 2013; Heong, 2012; Lile, 2014; Saltan, F., \& Divarci, O. F., 2017)

Various factors influence educational success with the primary objective of improving human resources. One of them is the teacher's skills to promote, assess, and evaluate learning outcomes. The skills are needed to determine the achievement of applied learning based on the curriculum (Budiman, 2014). Learners will learn more comprehensively and understand concepts better with HOTS. It is consistent with the notable characters of learning when learners could demonstrate their understanding of comprehensively and adequately. HOTS allows learners to understand different ideas and notions clearly, argue correctly, solve 
problems, construct an explanation, hypothesize, and understand complex matters to be more apparent.

HOTS is learning with productive learning outcome activities, especially in terms of social cognition, such as (1) sharing and receiving assistance, (2) transforming and completing information source, (3) collaborating and explaining concepts, (4) sharing various knowledge with peers, (5) sharing and receiving feedback, (6) completing the collaborative task, and (7) contributing to engage with challenges. The Regulation of Cultural and Educational Ministry Number 14 the Year 2018, referring to primary school learners' requirements about the minimum age to enroll (7 years old or minimally six years old started on July 1 ), then primary school learners could be considered at the level of the concrete stage. However, several fourthgraders of primary schools have been at the formal operational stage. Every development stage has different characteristics. According to Piaget (Byrnes, 2008), development makes a more abstract thought. Abstract thought is a skill to process information concerning objects, principles, and concepts. This thought cannot be physically realized into Higher Order Thinking skills. In a thinking context, abstract thinking is a low thinking level. From the explanation, this research aims to evaluate the process consistence of HOTS-oriented learning promoted in Primary Schools in Depok district, Special Region of Yogyakarta.

\section{Method}

This research is mixed-method research. It combines quantitative and qualitative approaches. On the other hand, the applied evaluation typed is program evaluation, focusing on finding out the 2013 curriculum HOTS implementation at the whole primary schools in Depok district, Special Region of Yogyakarta, based on the National Education rule Minister, number 22, the year 2006. Anderson \& Kratwohl's theory was used to evaluate the learning process, especially to evaluate the HOTS of the learners (Anderson, 2001). The applied evaluation model was Stake Countenance Model. This model emphasizes two primary matters: description and judgments. These two matters were obtained through (1) the Antecedent stage. It is a description of the High Order Thinking Skill learning orientation on the 2013 curriculum. The description deals with teachers' understanding of HOTS in the 2013 curriculum. (2) Transaction stage. It describes the implementation of HOTS-oriented learning in the 2013 curriculum. (3) Outcome stage. It is a measurement of the learning outcomes by using HOTS in the 2013 curriculum.

The research was conducted in Public and Private Primary Schools in Depok, Sleman, Special Region of Yogyakarta. It was carried out in October 2019; The population consisted of primary school teachers in Depok, Sleman, Special Region of Yogyakarta dealing with their HOTS-oriented learning implementation on the 2013 curriculum. The whole population consisted of 652 teachers with an error level of $5 \%$. Thus, the sample to take were 227 teachers. However, based on the teachers' conditions at the schools, two teachers were taken from each school (the lower and higher-level grades). Therefore, the final sample consisted of 30 participants. Here are the research population and sample table. By applying random sampling, stratified cluster random sampling, and several considerations, the results are: (1) the Public and Private Primary School Teachers, (2) the Lower and Higher Level Grade Teachers. The population and sample could be seen in Table 1.

Table 1. The numbers of population and sample

\begin{tabular}{ccc}
\hline School & Population & Sample \\
\hline The Whole Depok District & 98 & 30 \\
\hline
\end{tabular}

Based on the table, the population consists of 98 participants, while the sample consists of 30 participants from the whole Depok distric. 


\section{Result and Discussion}

This research evaluated Higher-Order Thinking Skill-oriented learning based on the 2013 curriculum for the whole Primary Schools in Depok, Sleman, Yogyakarta. This research emphasized two things: They were description and judgment. They were obtained through descriptions on the antecedent preliminary stage, transaction process stage, and outcome stage. The preliminary antecedent stage described HOTS implementation. It was about teachers' understanding concerning HOTS. The transaction process dealt with HOTS-based learning management. This stage described HOTS-based learning implementation on the field. Then, the last one dealt with the outcome stage. It consisted of HOTS-based learning assessment. Several categories to assess them were based on the Regulation of Cultural and Educational Ministry Number 104 the Year 2014 about Learning Outcomes from Educators at Primary and Senior Education levels.

The minimum mastery standard criterion for the cognitive aspect reached an average score of 2.67 (Fair) labeled (B). The minimum mastery standard criterion reached an optimum achievement score of 2.67 (fair) labeled (B-). The minimum standard mastery criterion for affective aspect (BC of $\mathrm{CC}-1$ and $\mathrm{CC}-2$ ) reached a predicate of $\mathrm{B}$, minimally 2.85 .

Table 2. The teachers' conditions toward HOTS-based learning implementation

\begin{tabular}{|c|c|c|c|c|}
\hline Number & Score Range & Criteria & Total & Percentage \\
\hline 1 & $\geq 30,01$ & Very Excellent & 2 & $6.6 \%$ \\
\hline 2 & $26.2-30.0$ & Excellent & 5 & $16.6 \%$ \\
\hline 3 & $22.4-26.1$ & Low & 14 & $46.6 \%$ \\
\hline \multirow[t]{4}{*}{4} & $\leq 22.4$ & Very insufficient & 9 & $30 \%$ \\
\hline & & Total & 30 & $100 \%$ \\
\hline & & $\begin{array}{l}\text { Percentage of } \\
\text { category }\end{array}$ & excellent & $23.2 \%$ \\
\hline & & Lower percentag & & $76.6 \%$ \\
\hline
\end{tabular}

Based on the table, two teachers, $6.66 \%$, were categorized as very excellent to apply HOTS-based learning. Five teachers were categorized as excellent (16.6\%). On the other hand, fourteen teachers were categorized fairly (46.66\%). Then, nine teachers were categorized low (30\%). The teacher condition data description in the form of a diagram.

\section{The Evaluation Result Diagram of HOTS-based learning implementation for the whole Primary Schools in Depok, Yogyakarta}

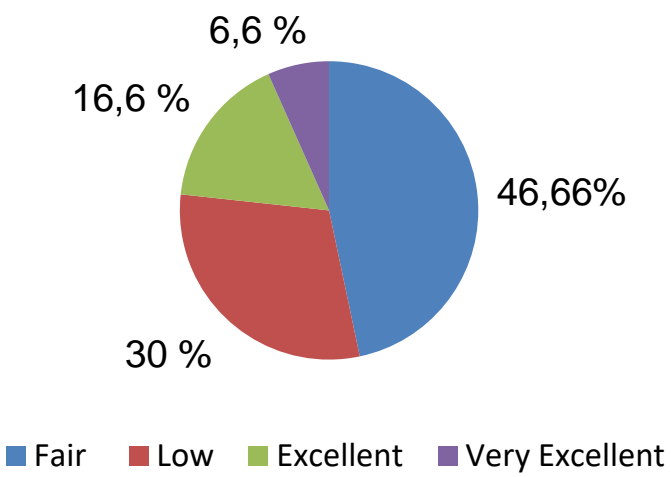

Figure 1. HOTS-based learning evaluation results. 
The Table shows that low-category teachers' differences are higher than those of excellent category teachers, with a percentage difference of $53.46 \%$. An evaluation tool is an instrument. It determined the teachers' success in sharing the learning objective. This statement is supported by (Basuki, I \& Haryanto, 2014). They argue that evaluation is an identification activity to find out whether an already designed program has successfully and efficiently achieved the objectives or not. The ministry has applied an assessment for teachers. It should contain a Higher Order Thinking Skills. This statement is stated in the revised 2013 curriculum concerning the assessment standard domain.

Higher-order thinking is a mental-involvement activity with ideas, objects, and situations through analogical, elaborative, inductive, deductive, and transformative ways (Schraw, 2011). They should show orientation toward complexity, generative knowledge, evidence investigation, and reflection. HOTS requires skills to remember and analyze, synthesize, and evaluate (Yuriza, 2018). The analytical process involved activity in differing, organizing, and interacting. On the other hand, the evaluation process involved checking and criticizing activities. The next one, the creating process, took creating, planning, and producing activities (Hanoum, 2017).

The evaluated matters were the teacher's understanding of HOTS-oriented learning, lesson plan design, and learning realization. HOTS-oriented learning aims to improve the higher-order thinking skill of every learner. The textbooks, either the teacher or learner books in the 2013 curriculum, had been provided by the government. Therefore, teachers should review the curriculum to arrange a syllabus and lesson plan. Teachers had to compose syllabus and learning plans with HOTS orientations. They should analyze the learning materials to keep their consistency to the graduate standard, core competence, and basic competence. All of them should be HOTS-oriented based on Bloom's taxonomy. The designed lesson plan should involve higher thinking skills. They were such as analyzing, reflecting, arguing, applying concepts in a different situation, arranging, and creating.

HOTS could be reached by applying learner-centered learning. It allows learners to express their ideas freely to develop HOTS (Sucipto, 2017). Learners should master HOTS since $21^{\text {st }}$-century educational demand (Amalia, 2013; Darma, 2008; 21stCentury Skills for Students and Teachers., 2010; Somakim, 2016; Sudarisman, 2016). The observation was carried out to determine the facts dealing with the lesson plan and the evaluative instruments used by lower and higher-level grade teachers.

In addition to observation, interviews were also used for the teachers. The results showed (a) teachers had not been able to apply HOTS in the learning; (b) several learners had difficulties keeping up with HOTS-based learning, and (c) teachers had difficulties in obtaining relevant literature about HOTS. A study conducted by (Ningsih 2020) showed that: (1) Higherorder thinking skill implementation plan of thematic learning themed 5 (ecosystem) for the fifthgraders at Public Primary School Tunjungsekar 3 Malang contained analyzing (C4), evaluating (C5), and creating indicators (C6) in their lesson plan; (2) HOTS implementation on the same theme for fifth graders of Public Primary School Tunjungsari 3 was based on Discovery Learning.

A study conducted by (Sigit 2019) also found that the learners' scores at primary school level were higher than those at Junior High School level.. Meanwhile, at Junior High School level, it was higher than BP level. It was due to changes of the applied curriculum several years ago. 2013 curriculum is a new curriculum that emphasizes on learner-centeredness instead of teacher-centeredness. It influenced the learners' HOTS. For the BP level, learners taught by the 2006 Educational Unit Level Curriculum (KTSP) 10 years ago had lower HOTS. It was due to the previous curriculum was the teacher-centered curriculum.

A study conducted by (Jaelani 2017) showed that: (1) PBL implementation was more effective than expository implementation to improve the learners' HOTS; (2) before the implementation, PBL was more effective compared to expository implementation to build learners' characters; and (3) the engaged problems in promoting PBL process were about teacher's unreadiness, time allotment, heterogeneous learners' inputs, learning habits of the learners, and difficult assessment. 
A study conducted by (Widyaningsih 2020) showed that the developed learning media was categorized valid for all assessment aspects. They were such as layout, navigation, function, and pedagogy. Besides, learners' responses toward the applied interactive multimedia were effective and practiced in all assessment aspects. The learners appropriately responded toward HOTS skills. They could be developed during a learning process, included their analyzing, evaluating, and creating skills. Therefore, HOTS-oriented interactive multimedia through e-learning could be applied in physics learning. A study conducted by Dewi Endah Sari (Sari, 2020) showed that HOTS of female learners' achievements were not far different from those of male learners. Through this finding, Biology learning implementation at schools should also be innovative with various creative media to empower HOTS for male and female learners.

The research aimed to describe the HOTS implementation plan, Problem Based Learning plan toward learners and the engaged hindrances, to measure HOTS at various educational levels by using HOT-AEP, to improve HOTS and characters of the learners, to develop interactive multimedia with a purpose of e-learning, and to find out the sex type influences toward HOTS empowerments of the learners. Meanwhile, this research evaluated the teachers' understanding of HOTS-oriented learning characteristics, the lesson plan, and the evaluation at the whole primary schools of Depok district, Sleman municipality, Special Region of Yogyakarta, a mixed-method approach. The findings showed that HOTS-oriented learning had not been achieved ultimately, both from the teachers' understanding of the learning processes. Therefore, this research could be used as relevance and reference concerning HOTS-implementation evaluation at schools and teachers' skill improvement to promote HOTS for all learning components.

\section{Conclusions and Suggestions}

HOTS-based learning implementation at primary schools in the Depok district had been carried out, although it was not maximal and in line with the 2013 regulation of Cultural and Educational Ministry. Therefore, there is a need for the government to socialize so that all teachers understand HOTS and could apply HOTS learning at schools based on the 2013 Regulation of Cultural and Educational Ministry. This research evaluated HOTS and expected to contribute to the educational world. It is primarily for educators to not only apply C-1 level (Cognitive Level) strategies, models, and learning methods; C-2 level (understanding) and C3 level (applying). They are expected to apply the C-4 level (analyzing), C-5 level (evaluating or synthesizing), and C-6 level (creating) that are oriented on HOTS.

\section{References}

Amalia, R. (2013). Penerapan model pembelajaran pembuktian untuk meningkatkan kemampuan berpikir matematis tingkat tinggi siswa SMA (Doctoral dissertation, Universitas Pendidikan Indonesia).

Anderson, L. W., \& Bloom, B. S. (2001). A taxonomy for learning, teaching, and assessing: A revision of Bloom's taxonomy of educational objectives. Longman.

Baird, J., Andrich, D., Hopfenbeck, T. N., \& Stobart, G. (2017). Assessment and learning: fields apart? Assessment in Education: Principles, Policy \& Practice, 24 (3), 317-350. https://doi.org/10.1080/0969594X.2017.1319337.

Baris, M. F. (2015). European teachers' technological pedagogical content knowledge (TPCK) and educational use of web technologies. European Journal of Educational Research, 4(4), 149-155. https://doi.org/10.12973/eujer.4.4.149.

Basuki, I \& Haryanto. (2014). Asesmen Pembelajaran. PT Remaja Rosdakarya.

BSNP. (2018). Penerapan Soal Model HOTS dalam Ujian Nasional Perlu Diimbangi dengan Peningkatan Kemampuan Guru dan Siswa. Badan Standar Nasional Pendidikan. http://bsnpindonesia.org/2018/04/21/penerapan-soal-model. 
Budiman, A., \& Jailani, J. (2014). Pengembangan instrumen asesmen higher order thinking skill (HOTS) pada mata pelajaran matematika SMP kelas VIII semester 1. Jurnal Riset Pendidikan Matematika, 1(2), 139-151. https://doi.org/10.21831/jrpm.v1i2.2671.

Budsankom, P., Sawangboon, T., Damrongpanit, S., \& Chuensirimongkol, J. (2015). Factors Affecting Higher Order Thinking Skills of Students: A Meta-Analytic Structural Equation Modeling Study. Educational Research and Reviews, 10(19), 2639-2652. https://eric.ed.gov/?id=EJ1080273.

Byrnes, J. (2008). Cognitive development and learning in instructional contexts. Pearson Education, Inc.

Center, P. P. R. (2010). 21st Century Skills for Students and Teachers. Honolulu: Kamehameha Schools. Research \& Evaluation Division. Research \& Evaluation Division.

Copley, P. (2013). The need to deliver higher-order skills in the context of marketing in SMEs. Industry and Higher Education, 27(6), 465-476. https://doi.org/10.5367/ihe.2013.0181.

Darma, M. (2008). Teknik penyusunan tes dan nontes. Mitra Cindikia.

Deviana, T., \& Kusumaningtyas, D. I. (2019). Analisis Kebutuhan Penyusunan Perangkat Pembelajaran Tematik Berbasis HOTS (Higher of Order Thinking Skills) pada Kurikulum 2013 di SD Muhammadiyah 05 Batu. Edumaspul: Jurnal Pendidikan, 3(2), 64-74. https://doi.org/10.33487/edumaspul.v3i2.141.

Driana, E., \& Ernawati, E. (2019). Teachers' understanding and Practices in Assessing Higher Order Thinking Skills at Primary Schools. Acitya: Journal of Teaching and Education, 1(2), 110-118. https://journals.umkt.ac.id/index.php/acitya/article/download/233/109.

Farisi, M. (2016). Developing the 21 st-century social studies skills through technology integration. Turkish Online Journal of Distance Education-TOJDE, 17(1), 16- 30. https://doi.org/10.17718/tojde.47374.

FitzPatrick, B., \& Schultz, H. (2015). Do curriculum outcomes and assessment activities in science encourage higher-order thinking? Canadian Journal of Science, Mathematics and Technology Education, 136-154. https://doi.org/10.1080/14926156.2015.1014074.

Garcia, L. (2015). Environmental Science Issues for Higher- Order Thinking Skills (HOTS) Development: A Case Study in the Philippines. In Biology Education and Research in a Changing Planet, (45-54). https://doi.org/10.1007/978-981-287-5242.

Hanoum, R. N. (2014). Mengembangkan keterampilan berpikir tingkat tinggi mahasiswa melalui media sosial. Edutech, 13(3), 400-408. https://doi.org/10.17509/edutech.v13i3.3093.g2114.

Heong, Y. M., Yunos, J. M., Othman, W., Hassan, R., Kiong, T. T., \& Mohamad, M. M. (2012). The needs analysis of learning higher order thinking skills for generating ideas. Procedia-Social and Behavioral Sciences, 59, 197-203. https://doi.org/10.1016/j.sbspro.2012.09.265.

Ichsan, I. Z., Sigit, D. V., Miarsyah, M., Ali, A., Arif, W. P., \& Prayitno, T. A. (2019). HOTS-AEP: Higher Order Thinking Skills from Elementary to Master Students in Environmental Learning. European Journal of Educational Research, 8(4), 935-942. https://eric.ed.gov/?id=EJ1231652.

Jailani, J. (2014). Pengembangan Bahan Ajar Matematika yang Berorientasi pada Karakter dan Higher Order Thinking Skill (HOTS). PYTHAGORAS: Jurnal Pendidikan Matematika, 9(1), 45-59. https://doi.org/10.21831/pg.v9i1.9063. 
Jailani, J., Sugiman, S., \& Apino, E. (2017). Implementing the problem-based learning in order to improve the students' HOTS and characters. Jurnal Riset Pendidikan Matematika, 4(2), 247-259. https://doi.org/10.21831/jrpm.v4i2.17674.

Lile, R., \& Bran, C. (2014). The assessment of learning outcomes. Procedia-Social and Behavioral Sciences, 163, 125-131. https://doi.org/10.1016/j.sbspro.2014.12.297.

Mendikbud. (2013). Peraturan Menteri Pendidikan dan Kebudayan RI No. 67 Tahun 2013 Tentang KD dan Struktur Kurikulum SD/MI (pp. 80). Kementerian Pendidikan dan Kebudayaan.

Ningsih, S. W. (2020). Penerapan Higher Order Thinking Skills (HOTS) Pada Pembelajaran Tematik Tema 5 (Ekosistem) Kelas 5 di SDN Tunjungsekar 3 Malang (Doctoral dissertation, Universitas Muhammadiyah Malang).

Riadi, A., \& Retnawati, H. (2014). Pengembangan perangkat pembelajaran untuk meningkatkan HOTS pada kompetensi bangun ruang sisi datar. PYTHAGORAS: Jurnal Pendidikan Matematika, 9(2), 126-135. https://doi.org/10.21831/pg.v9i2.9074.

Saltan, F., \& Divarci, O. F. (2017). Using blogs to improve elementary school students' environmental literacy in science class. European Journal of Educational Research, 6(3), 347-355. https://doi.org/10.12973/eu-jer.6.3.347.

Sari, D. E., Hindun, I., Mahmudati, N., Miharja, F. J., \& Fauzi, A. (2020). Are Male and Female Students Different in High-Order Thinking Skills? JPI (Jurnal Pendidikan Indonesia), 9(1), 42-48. http://dx.doi.org/10.23887/jpi-undiksha.v9i1.17575.

Schraw, G., \& Robinson, D. H. (Eds.). (2011). Assessment of higher order thinking skills. Information Age Publishing, Inc.

Setiawati, S. (2019, February). Analisis Higher Order Thinking Skills (HOTS) Siswa Sekolah Dasar dalam Menyelesaikan Soal Bahasa Indonesia. In Prosiding Seminar Nasional Pendidikan KALUNI (Vol. 2).

Sucipto, S. (2017). Pengembangan keterampilan Berpikir Tingkat Tinggi dengan Pengembangan strategi Model metakognitif Pembelajaran problem based learning. Jurnal Pendidikan (Teori dan Praktik), 2(1), 63-71. https://doi.org/10.26740/jp.v2n1.p77.

Suryapuspitarini, B. K., Wardono, W., \& Kartono, K. (2018, February). Analisis soal-soal matematika tipe Higher Order Thinking Skill (HOTS) pada kurikulum 2013 untuk mendukung kemampuan literasi siswa. In PRISMA, Prosiding Seminar Nasional Matematika (Vol. 1, pp. 876-884).

Widyaningsih, S. W., Yusuf, I., Prasetyo, Z. K., \& Istiyono, E. (2020). Online interactive multimedia oriented to HOTS through e-learning on physics material about electrical circuit. JPI (Jurnal Pendidikan Indonesia), 9(1), 1-14. http://dx.doi.org/10.23887/jpiundiksha.v9i1.17667.

Yuriza, P. E., \& Sigit, D. V (2018). Hubungan antara kemampuan berpikir tingkat tinggi dan tingkat kecerdasan dengan kemampuan literasi sains pada siswa SMP. Biosfer: Jurnal Pendidikan Biologi, 11(1), 13-20. 